\title{
Mercury in Stream Ecosystems- New Studies Initiated by the U.S. Geological Survey
}

\author{
By Mark E. Brigham, David P. Krabbenhoft, and Pixie A. Hamilton
}

\section{Why study mercury?}

Mercury can adversely affect humans and wildlife through consumption of contaminated fish, particularly by sensitive individuals, such as children and women of childbearing age. Mercury is currently the leading cause of impairment in the Nation's estuaries and lakes and was cited in nearly 80 percent of fish-consumption advisories $(2,242$ of 2,838$)$ reported by states in 2000. The geographic extent of mercury advisories covers more than 10 million acres of lakes and more than 400,000 stream miles-increases of about 7 and 48 percent, respectively, over advisories reported in 1998 (U.S. Environmental Protection Agency, 2002a).

\section{Understanding the mercury cycle}

Our understanding of mercury contamination has evolved considerably since the 1950's, when the problem was perceived to be associated primarily

\section{Facts about mercury:}

- Highly toxic to the nervous system

- Persistent in the environment

- Bioaccumulates (higher concentrations in tissues of aquatic plants and animals than in water)

- Biomagnifies (higher concentrations at increasingly higher levels in the food chain)

- Numerous chemical forms in air, water, sediment, and biota

- Responsible for nearly 80 percent of U.S. fish-consumption advisories with a limited number of point sources of severe pollution, such as industrial or mining wastes. We now know that mercury contamination is global and affects many waters that have no obvious mercury source. This is because mercury emissions generally disperse widely in the atmosphere before being deposited to the earth's surface. Mercury is emitted by natural sources, such as volcanoes, geothermal springs, geologic deposits, and the ocean. Human-related sources primarily include coal combustion, waste incineration, industrial uses, and mining. During the last 150 years, human activities have more than doubled natural amounts of mercury in the atmosphere (Schuster and others, 2002).

Inorganic mercury (the form emitted to the environment) is generally not a health concern-it is poorly absorbed by the digestive tract. The real issue is methylmercury - an organic form that is highly toxic to the nervous system. Methylmercury is produced from inorganic mercury by methylation, a microbial process

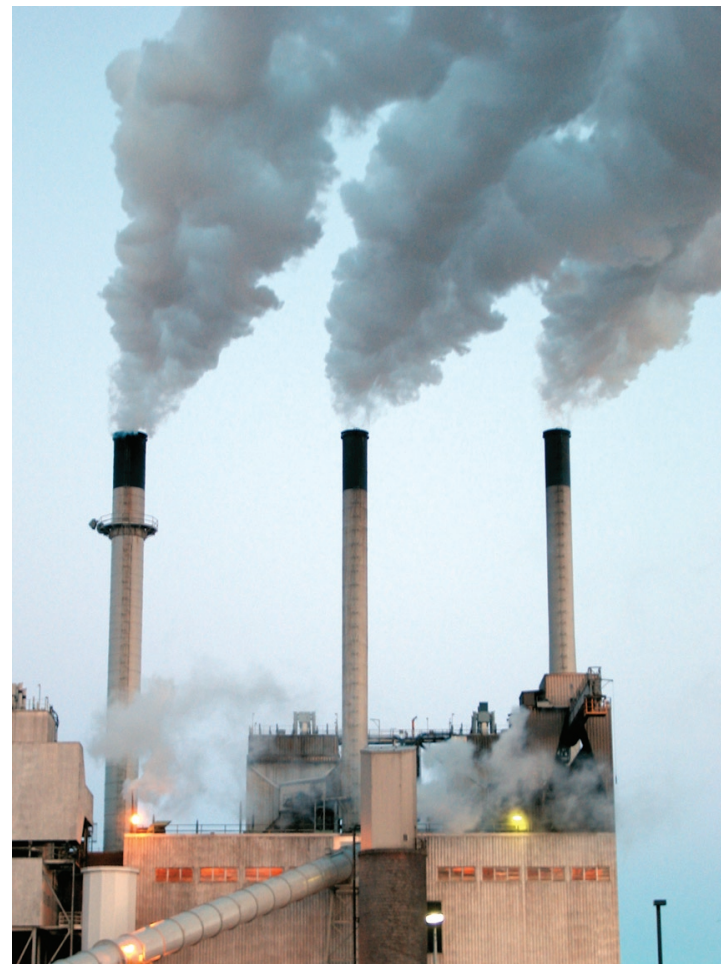

Mercury contamination is widespread globally, originating from natural and human-related sources, including air transport from coal combustion, waste incineration, and mining. (Photograph by Phillip J. Redman, U.S. Geological Survey). that is controlled by certain bacteria and enhanced by chemical and environmental variables, such as the presence of organic matter and oxygen. More than 95 percent of all mercury in fish is methylmercury, and this form of mercury biomagnifies to high concentrations at the top of food chains (Wiener and others, 2002).

During the last 15 years, scientists have increased their understanding of mercury in standing water, such as lakes, reservoirs, and wetlands. Less understood are details of the mercury cycle-from source to fish-in stream ecosystems. Data are sparse for mercury in all components of stream ecosystems, including water, sediment, and aquatic biota. Data also are lacking on the transport, biological and chemical transformation, and bioaccumulation of mercury in streams in diverse geographical locations and ecological settings. USGS studies are designed to enhance scientific understanding of mercury in stream ecosystems. 


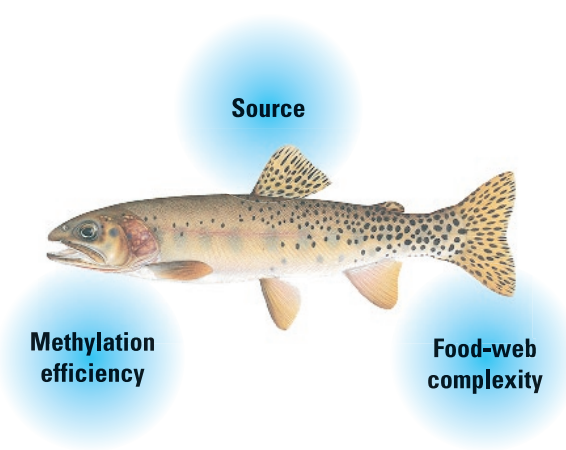

Mercury levels in fish are determined by (1)-mercury sources, such as atmospheric emissions from burning coal; (2) methylation efficiency, which is controlled by certain biological, chemical, and environmental characteristics; and (3) food-web complexity, the totality of feeding interactions-from algae to predatory fish-in an ecological community.

\section{USGS mercury studies}

USGS mercury studies address two primary questions: (1) What are the concentrations of mercury in water, sediment, and fish? and (2) How do biological, chemical, and other environmental characteristics govern the methylation, transport, and bioaccumulation of mercury in streams? These studies include stream ecosystems in relatively undeveloped forested areas and in highly urbanized areas (such as Portland, Oregon; Milwaukee, Wisconsin; and, Orlando, Florida) to allow comparisons among these contrasting land uses. The studies also cover a wide range of landscapes with varying geology, climate, hydrology, and wetland density to better understand environmental factors controlling methylation, mercury transport, and bioaccumulation. Finally, the stream ecosystems vary in food-web complexity, which can influence mercury bioaccumulation and biomagnification. Specifically, the studies assess:

- Atmospheric deposition of inorganic mercury to ecosystems.

- Processes affecting the formation and degradation of methylmercury, including (1) methylmercury dissolved in water and bound to sediment (which can differ in uptake by aquatic biota); (2) methylation rates in relation to microbial processes, chemical characteristics in water and sediment (including acidity $(\mathrm{pH})$, temperature, dissolved organic carbon, and sulfate), environmental settings, and seasons; and (3) demethylation processes, which convert methylmercury to less toxic forms of mercury and, thereby, decrease the amount of methylmercury available to aquatic biota.

- Other geochemical forms of mercury in the atmosphere, water, and sediment.

- Food-web complexity (the totality of feeding interactions-from algae to aquatic insects to forage and predatory fish) and its influence on bioaccumulation of mercury.

\section{Mercury is studied in stream eco- systems across the Nation}

USGS is assessing the extent and magnitude of mercury contamination in stream ecosystems in 14 major river basins across the continental United States (referred to as "Study Units" by the National Water-Quality Assessment (NAWQA) Program) (see map). Samples of water, sediment, and predatory fish were collected at 120 stream sites in 2002 to assess the occurrence of total mercury, methylmercury, and other chemical constituents, such as sulfate and dissolved organic carbon. This one-time, "snap-

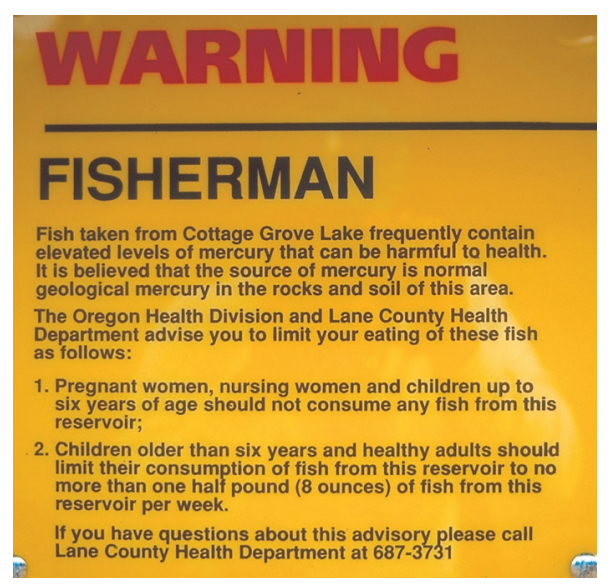

Fish consumption warnings are posted to warn anglers. The number of states that have issued mercury advisories has risen steadily from 27 in 1993 to 44 in 2002 (U.S. Environmental Protection Agency, 2002b)

shot" assessment covers a multitude of diverse environmental settings.

In addition, USGS is assessing processes affecting transport, biological and chemical transformations, and bioaccumulation of mercury in 3 of the 14 Study Units. These more intensive studies began in 2001 in the Willamette Basin, Georgia-Florida Coastal Plain Drainages, and Western Lake Michigan Drainages. Similar studies in six additional Study Units will begin in 2004 or 2007.

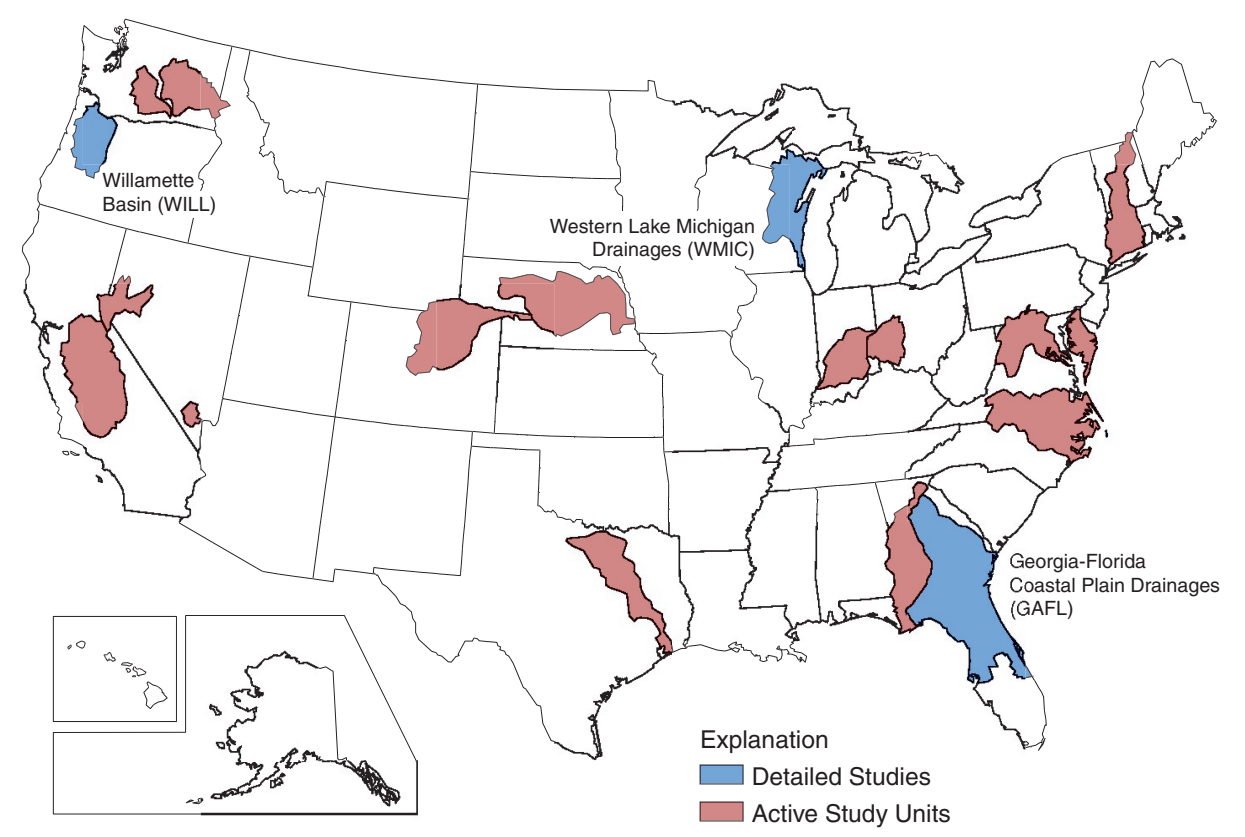

Samples for analysis of mercury were collected at 120 stream sites in 14 major river basins (NAWQA "Study Units") in 2002. More detailed studies on mercury methylation, transport, and bioaccumulation are ongoing in 3 of the 14 Study Units - the Willamette Basin, Georgia-Florida Coastal Plain Drainages, and Western Lake Michigan Drainages 


\section{How USGS information can be used}

\section{Identifying high-priority regions}

USGS mercury data will help to fill information gaps for stream ecosystems in many regions of the United States for which little or no information on mercury contamination exists. These assessments will help to better define and anticipate regional variations in aquatic mercury levels and to identify contaminated and high-priority regions for protection and restoration.

USGS findings will contribute to improved mercury criteria and standards. The current U.S. Environmental Protection Agency criterion is based on mercury concentrations in fish because there is not enough information about mercury in water or about bioaccumulation of mercury in fish to establish a water standard. Because USGS studies relate concentrations of mercury in water to mercury concentrations in fish, the validity for establishing a water standard can be evaluated, which will ultimately allow a more timely and cost-effective

\section{Improved criteria and standards for pro- tecting aquatic and human health}

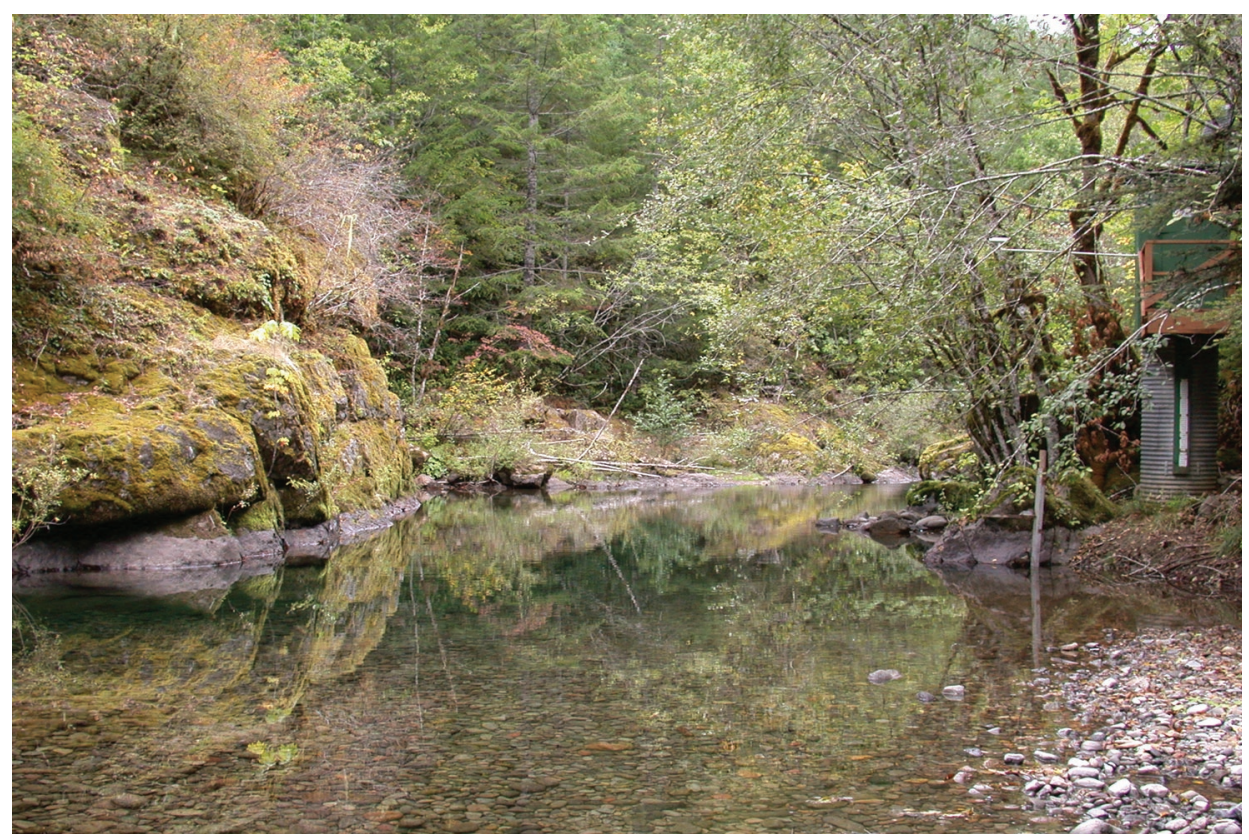

While most research in the last 15 years has focused on mercury contamination in lakes, reservoirs, and wetlands and in portions of rivers receiving point-source discharges of industrial and mining wastes, USGS studies will help to fill large information gaps in terms of basic data and detailed studies of stream ecosystems across the Nation, such as in the Willamette River Basin shown above. (Photograph by Dennis A. Wentz, U.S. Geological Survey). approach for regulating mercury. In addition, USGS data and research may aid in the development of more rigorous models that relate water quality to mercury bioaccumulation, thereby enhancing capabilities for predicting mercury contamination in fish.

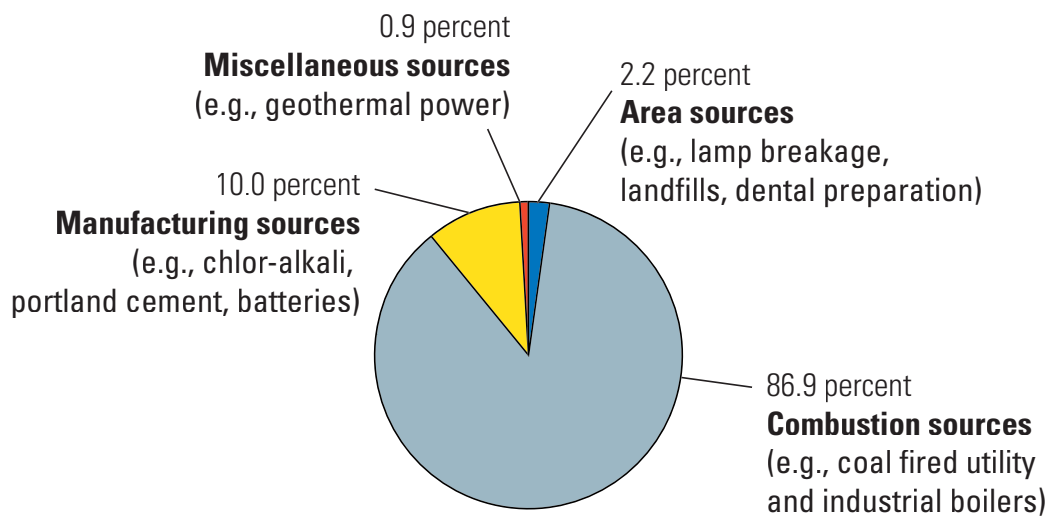

Combustion from coal-fired utilities and industrial boilers accounts for more than 85 percent of the transmission of inorganic mercury to the atmosphere (U.S. Environmental Protection Agency, 1997). USGS findings will provide a better understanding of what drives methylation of inorganic mercury in certain environmental settings, and thereby help to clarify appropriate strategies regarding mercury emissions.

\section{Improved strategies for controlling emis- sions and managing lands}

USGS findings will provide a better understanding of the methylation of mercury in various environmental settings. This understanding will help to clarify the most appropriate strategies for defining and achieving safe mercury emission levels. For example, if sulfur is linked conclusively to the mercury cycle, there may be implications for the control of both sulfur and mercury emissions from power plants. In addition, research on environmental characteristics that enhance mercury methylation may help to avoid mercury contamination in the creation of reservoirs and flooding of lands in vulnerable areas. 


\section{Multiple USGS programs collabo- rate on mercury studies}

USGS mercury assessments are planned and implemented in large part through the National Water-Quality Assessment (NAWQA) Program ( a map can be accessed at the NAWQA Web site at http://water.usgs.gov/nawqa). In 1991, NAWQA began evaluating the quality of streams, ground water, and aquatic ecosystems in 51 major river basins and aquifer systems (known as "Study Units") across the Nation. The assessments characterize the ambient water resource - the source of about 60 percent of the Nation's drinking water and water for industrial, irrigation, and recreational uses. During its first decade, NAWQA made baseline assessments of pesticides, nutrients, volatile organic compounds, trace elements, dissolved solids, and radon in streams and ground water, as well as the condition of aquatic habitats and fish, insect, and algal communities. These findings are described in hundreds of reports (access NAWQA Web site above).

In the next decade of studies, 42 of the Study Units will be intensively reassessed to determine trends at many of the streams and ground-water monitoring sites; fill critical gaps in characterizing water-quality conditions; and build upon earlier NAWQA findings that show how natural features and human activities affect water quality and aquatic ecosystems. Mercury is one of five national priority topics that will be addressed in the second decade of NAWQA studies. Four remaining topics include (1) effects of urbanization on stream ecosystems;

(2) ecological effects of nutrient enrichment; (3) transport of contaminants to public-supply wells; and, (4) sources, transport, and fate of agricultural chemicals.

The NAWQA work is enhanced through research conducted by the USGS Toxic Substances Hydrology (TOXICs) Program, National Research Program (NRP), and various programs within the USGS Geology and Biology disciplines. This collaborative research largely focuses on chemical and biological processes controlling mercury transport, cycling, and biomagnification in stream ecosystems. Specifically, the different programs provide the following expertise:
Toxic Substances Hydrology Program (TOXICs) - Mercury cycling; chemical transformations and physical partitioning of mercury; stateof-the-art analytical methods ( $h t t p$ : //toxics.usgs.gov).

National Research ProgramMicrobial and chemical reaction rates (including sulfate reduction and mercury methylation and demethylation); mercury bioaccumulation (http://water.usgs.gov/ $n r p)$.

Programs in the USGS Geology Discipline-Mercury methylation as it relates to sulfur geochemical cycling and sources (http://geology.usgs.gov).

Programs in the USGS Biology Discipline-Effects of mercury on fish health, including reproductive success, hormone levels, and genetic damage; occurrence of mercury in fish-eating birds (http://biology.usgs.gov).

The USGS promotes public access to water-quality information. Visit USGS Web sites listed above to access reports, water-quality data, and maps. For additional information, please contact:

Mark E. Brigham, Mercury

Team Leader, (763) 783-3274,

mbrigham@usgs.gov

David P. Krabbenhoft, Mercury

Team Lead Scientist, (608) 821-3843, dpkrabbe@usgs.gov

Lynda S. Chasar, Georgia-Florida Coastal Plain Drainages, (850) 942-9500, ext.3010,lchasar@usgs.gov

Barbara C. Scudder, Western Lake Michigan Drainages, (608) 821-3832, bscudder@usgs.gov

Dennis A. Wentz, Williamette Basin, (503) 251-3296,dawentz@usgs.gov

Timothy L. Miller, Chief of Water Quality Programs, USGS, (703) 6485716,tlmiller@usgs.gov

\section{Cited literature:}

Schuster, P.F., Krabbenhoft, D.P., Naftz, D.L., Cecil, L.D., Olson, M.L., DeWild, J.F., and Green, J.R., 2002, A 270-year ice core record of atmospheric mercury deposition to western North America, Environmental Science and Technology, v. 36, pp. 2303-2310.

U.S. Environmental Protection Agency, 2002a, National water quality inventory-2000 Report, U.S. Environmental Protection Agency Report EPA841-R-02-001, Washington D.C.

U.S. Environmental Protection Agency, 2002b, Update: National listing of fish and wildlife advisories, EPA Fact Sheet EPA-823-F-02-007, Office of Water, Washington, D.C.

U.S. Environmental Protection Agency, 1997, Mercury study report to Congress, EPA 452R-97-004, Washington D.C.

Wiener, J.G., Krabbenhoft, D.P., Heinz, G.H., and Scheuhammer, A.M., 2002, Ecotoxicology of mercury, chap. 16, in D.J. Hoffman, B.A.Rattner, G.A. Burton, Jr., and J. Cairns, Jr., eds., Handbook of ecotoxicology, 2nd ed.: Boca Raton, Fla., CRC Press, p. 407-461.

\section{For suggested further reading on mercury in stream ecosystems, refer to:}

http://infotrek.er.usgs.gov/mercury 